DOI: https://doi.org/10.36910/6775-2524-0560-2021-44-08

УДК 004.02

Поплавська Ганна Володимирівна, викладач інформатики

Курдельчук Григорій Пантелеймонович, викладач ТЗН.

Комунальний заклад вищої освіти «Луцький педагогічний коледж» Волинської обласної ради, м. Луцьк

\title{
ФОРМУВАННЯ У СТУДЕНТІВ САМОСТІЙНОЇ ПІЗНАВАЛЬНОЇ ДІЯЛЬНОСТІ ПРИ ВИВЧЕННІ ІНФОРМАТИКИ
}

\begin{abstract}
Поплавська Г. В., Курдельчук Г. П. Формування у студентів самостійної пізнавальної діяльності при вивченні інформатики. У статті розглядаються питання формування самостійної пізнавальної активності у студентів методами діяльнісного підходу на заняттях інформатики. Звертається увага на роль діяльнісного підходу для активізації самостійної пізнавальної діяльності.
\end{abstract}

Ключові слова: самостійна пізнавальна діяльність, самостійна робота, діяльнісний підхід, мотивація.

Поплавская А. В., Курдельчук Г. П. Формирование у студентов самостоятельной познавательной деятельности при изучении информатики. В статье рассматриваются вопросы формирования самостоятельной познавательной активности студентов методами деятельностного подхода на занятиях информатики. Обращается внимание на роль деятельностного подхода для активизации самостоятельной познавательной деятельности.

Ключевые слова: самостоятельная познавательная деятельность, самостоятельная работа, деятельностный подход, мотивация.

Poplavska G.V., Kurdelchuk G.P. Framing in students of late-stage activities in the study of infirmacy. In the article there are the question of the framing of independent cognitive activity among students by the methods of activity approach in computer science classes. Attention is paid to the role of the activity approach for the activation of independent cognitive activity.

Keywords: independent cognitive activity, independent work, activity approach, motivation.

Постановка наукової проблеми. Думаючи про людину XXI століття, яка сьогодні навчається в коледжі і яка вивчає основи інформатики, ми турбуємось не про те, що вона запише на «флешку» своєї пам'яті, не про те, чи створить вона штучний інтелект, а зовсім про інше. Про те, як сьогодні сформувати мислення студента вільним і нетрафаретним.

Хороше заняття те, де панує ділова, творча атмосфера, де є бажання студентів міркувати, де вони охоче вступають в діалог 3 викладачем, один з одним, авторами тих чи інших теоретичних концепцій $\mathrm{i}$ положень. Адже хороше заняття, як правило, завжди вирізняється тим, що воно насичене різноманітними навчальними ситуаціями і кожна з них викликає у студентів велику кількість запитань, сумнівів, здивування, а часом і настороженість. Так народжуються в діяльності студентів дорогоцінні моменти, які підводять їх до пошуків, здогадок, до самостійної творчості.

Сучасним студентам доступні найрізноманітніші джерела інформації, але часто саме наявність готової інформації сприяє розвитку пасивності. Зникає прагнення до пошуку, пізнання, творчості, тобто діяльності. Для цього процес навчання має бути сконструйований з максимальним наближенням до запитів і можливостей студентів. Навчальний матеріал може здаватися студентам «сухим» і нецікавим, а тому завдання викладача спільно зі студентами - зробити його цікавим. Це можна зробити 3 використанням інформаційно-комунікаційних технологій, наукових фільмів, мережі Інтернет, окрім цього - використовуючи самостійну пізнавальну діяльність студентів (СПД). Слушно писав 3 цього приводу В. О. Сухомлинський, наголошуючи, що учень повинен не просто слухати і думати, а щось робити. Мислення має відображатись у діяльності, лише тоді на заняттях не буде байдужих і неуважних.

Основною тенденцією в розвитку освіти сьогодні $є$ перехід від традиційного (репродуктивного) навчання, як процесу запам’ятовування та відтворення, до продуктивного, творчого, як процесу розумового та особистого розвитку студента. У “Національній доктрині розвитку освіти" визначається одне із вагомих завдань - формування в молоді та дітей сучасного світогляду, розвитку творчих здібностей і навичок самостійного наукового пізнання, самоосвіти і самореалізації особистості. Зазначені соціальні завдання актуалізують проблему формування пізнавальної самостійності студентів, яка пов'язана 3 активізацією їх самостійної та самоосвітньої пізнавальної діяльності на заняттях інформатики.

Аналіз досліджень. Аналіз науково-педагогічної літератури дозволяє виділити кілька напрямів у дослідженні проблеми розвитку самостійної пізнавальної діяльності суб'єктів учіння.

Сутність самостійної пізнавальної діяльності, методику та технологію ії організації вивчали М.Г. Гарунов, Ю.К. Бабанський, М.Г. Дайрі, В.К. Буряк, Б.П. Єсіпов, М.О. Данилов, І.А. Зимня, І.Я. Лернер, В.К. Майборода, В.М. Манько, О.Я. Савченко, М.М. Скаткін, Н.Ф. Тализіна , Г.І. Щукіна, О.В. Усова, Л.В. Жарова та інші науковці. 
Психологічний нюанс самостійної пізнавальної діяльності розкрито в дослідженнях. Богоявленської Д.Б, Леонтьєва О.М., Менчинської Н.А., Гальперіна П.Я., Платонова К.К., Костюка Г.С., Петровского А.В., Смирнова С.Д., Рубінштейна С.Л..

Формування вмінь самостійної пізнавальної діяльності у студентів досліджували В.I. Бондар, О.Г. Мороз, В.І. Орлов.

Проаналізувавши психолого-педагогічні джерела, робимо висновок, що структура самостійної пізнавальної діяльності студентів знаходиться у перетині понять: “самостійності", “діяльності", “пізнання”, “пізнавальної діяльності”, “пізнавальної самостійності”, “самостійної роботи”.

Метою статті є розкрити та проаналізувати діяльнісний підхід на формування самостійної пізнавальної діяльності студентів Луцького педагогічного коледжу при вивченні інформатики.

\section{Виклад основного матеріалу й обгрунтування отриманих результатів дослідження.}

Узагальнюючи підходи науковців у дослідженні даної проблеми, можемо дати визначення: самостійна пізнавальна діяльність студентів - це комплекс дидактично передбачених зусиль, які збагачують інтелектуальну чутливість та сприяють поглибленому самостійному пошуку під керівництвом викладача тієї інформації (знань), котра “працює” на фаховий досвід (вміння та навички) та подальше професійне самовдосконалення.

Проаналізувавши праці вчених, можемо зробити висновок, що підгрунтям пізнавальної активності $\epsilon$ інтелектуальні вміння та здібності, готовність особистості до СПД, до вміння використовувати методику самостійного пошуку, цілеспрямованості, організованості, самоконтролю, здатність коригувати пізнавальну діяльність відповідно до певних методичних настанов.

Психолог С. Л. Рубенштейн писав, що становлення особистості можливе лише під час процесу змістовної діяльності; людина в процесі діяльності створює саму себе. [5]

Реалізація діяльнісного підходу для організації самостійної пізнавальної діяльності при вивченні інформатики у Луцькому педагогічному коледжі відбувається:

- під час навчального процесу, що, в свою чергу, розділяє самостійну роботу:

1) за програмою;

2) як доповнення до програми в поза навчальний час;

- поза навчальним процесом.

По формі організації самостійні роботи, які організовуємо, поділяємо на фронтальні, групові, парні, індивідуальні, які, в свою чергу, мають недиференційований (загальний) і диференційований (індивідуальний) вид.

Реалізація діяльнісного підходу на заняттях інформатики проходить покроково.

По-перше, продумуємо конкретні кроки реалізації схеми, яку пропонують психологи: потреби $\rightarrow$ мотиви $\rightarrow$ мета та завдання $\rightarrow$ дія $\rightarrow$ операція $\rightarrow$ результат $\rightarrow$ рефлексія.

По-друге, конкретизуємо такі компоненти: зміст матеріалу (чому вчити), мотиви діяльності, способи і форми організації праці (як вчити), засоби стимулювання роботи студентів, способи керівництва і форми контролю.

Зокрема, використовуємо два шляхи реалізації діяльнісного підходу на заняттях інформатики:

1) проведення цілих, закінчених занять, сконструйованих таким чином, що під час їх проведення, студенти самі здобувають знання і поглиблюють їх;

2) включення в традиційні заняття різних творчих завдань.

Як бачимо, цикл навчального пізнання може бути побудований аналогічно науковому пізнанню, i це в першу чергу стосується дослідницької діяльності. При цьому послуговуємось такими методичними порадами:

- Для залучення студентів до навчальної діяльності велике значення має мотивація. Пізнавальний мотив пов'язаний з інтересом, а тому його називають пізнавальний інтерес. Отже, необхідно забезпечити цей інтерес - важливу рушійну силу діяльності. Без інтересу будь-яка діяльність не $\epsilon$ ефективною.

- Діяльність починається з розумових дій, тому спочатку пропонуємо скласти план. У ньому повинні бути відповіді на три важливі питання: «Для чого роблю?», «Що роблю?» і «Як роблю?». Чим коротші відповіді, тим коротший шлях до досягнення мети.

- Намагаємось якомога менше навчального матеріалу подавати в готовому вигляді: всі або майже всі знання і вміння студенти повинні здобувати самостійно в процесі особистої роботи індивідуальної чи в колективі.

- Головна ознака самостійної діяльності полягає зовсім не в тому, щоб працювати без сторонньої допомоги, а в тому, що мета самостійної діяльності одночасно містить у собі функцію 
управління цією діяльністю. $Є$ відоме твердження, що нічому не можна навчити - можна тільки навчитися. Навчитися під керівництвом викладача, роль якого в ідеальному випадку зводиться до організації самостійної пізнавальної діяльності.

Щоб управляти процесом розвитку пізнавальної самостійної діяльності студентів, які щойно переступили поріг коледжу, обов'язково проводимо діагностику їх пізнавальної самостійності, тобто готовності самостійно оволодівати новими знаннями.

На нашу думку, пізнавальна самостійність як якість особистості визначається органічною єдністю трьох компонентів:

- Спонукального (наявність відповідних мотивів пізнавальної інтелектуальної діяльності);

- 3містового (володіння опорними знаннями і методами засвоєння нових знань);

- $\quad$ Texнічного (володіння необхідними формами і методами пізнавальної діяльності).

3 метою визначити найбільш значущі для студентів потреби, які вони прагнуть задовольнити під час навчальної діяльності, насамперед проводимо вивчення спонукальної сторони пізнавальної самостійності студентів. На першому ж занятті інформатики пропонуємо анкетування.

Анкета складається із трьох частин. Перша частина - це анкета - шкала, відповідаючи на запитання якої, треба не просто вибрати найбільш правильну із готових відповідей, але й оцінити в балах зі своєї точки зору кожну запропоновану відповідь (за 5-ти бальною шкалою оцінювання). Друга частина анкети дозволяє визначити мотиви пізнавальної самостійної діяльності і відношення студента до цього виду навчальної діяльності. Третя частина анкети складається із запитань, на які студент дає вільну відповідь, - це визначення для нього особисто місця інформатики в навчальному процесі і його інтересу до даного предмету. Аналіз анкети дозволяє організувати самостійну роботу кожного студента шляхом залучення його до певного виду навчальної діяльності.

Наступний крок діагностування - визначення рівня змістової сторони пізнавальної самостійності студентів (визначаємо наявність опорних знань, які $\epsilon$ необхідним елементом процесу пізнання). Запропонований тест визначає кількість залишкових знань студента з визначених тем.

I на кінець, з метою визначення рівня володіння формами і методами пізнавальної діяльності, з'ясовуємо початковий рівень технічної сторони пізнавальної самостійності студентів. Спочатку до відома студентів доводять основні знання змістового характеру, які необхідні для практичного втілення даної теми. Потім детально розглядають практичний зразок і пропонують серію завдань (наприклад, чотири завдання) для самостійної роботи, кожне із яких все істотніше відрізняється від зразка, потребує застосування нових прийомів і способів навчальних дій, що входять в структуру узагальненого методу розв'язування пізнавальних завдань. За максимальним номером правильно зробленого завдання визначають рівень технічної сторони пізнавальної самостійності студентів.

В результаті анкетування виділяємо чотири основних види вмінь самостійної пізнавальної діяльності студентів:

Репродуктивно-пізнавальні вміння. Дії тільки за зразком, узагальнення відсутні або носять емпіричний характер, виклад матеріалу копіюється, зв'язок між системою знань та системою вмінь практично відсутній.

Інструментально-алгоритмічні вміння. Під час виконання завдань спостерігаються аналогічно міцніші стереотипні знання, узагальнення емпіричного характеру, зв'язок між системою знань та системою вмінь слабкий.

Продуктивно-перетворювальні вміння. Під час виконання завдань переважає індуктивнопошуковий підхід, студент самостійно використовує аналогії; узагальнення на дедуктивно-доказовому рівні з елементами індукції.

Творчо-пошукові вміння. Студент здатний самостійно замінити проблему та вибрати шляхи ії вирішення; узагальнення здійснюється на теоретичному рівні, знання та вміння утворюють єдину систему, зв'язок між предметами усвідомлюється на світоглядному та рефлексивному рівнях.

Вибір варіанта для організації індивідуальної самостійної роботи студента здійснюємо у відповідності до визначеного рівня його пізнавальної активності.

Спираючись на принципи розвивального навчання, при організації індивідуальної самостійної роботи студентів намагаємося дотримуватися таких вимог:

- кожен студент повинен отримати завдання, яке йому під силу в даний момент часу;

- кожен студент повинен мати можливість виконувати більш важке і творче завдання;

- кожному студенту слід дати можливість виконувати такі завдання, які він сам вважає відповідними його індивідуальності. 
Саме 3 таких позицій ми намагаємося організовувати самостійну роботу студентів, яка постає як засіб організації навчального чи наукового пізнання студента, і як форма виявлення ним певного способу діяльності стосовно виконання відповідного навчального завдання з метою одержання нових знань або поглиблення і впровадження уже існуючих знань у практичну діяльність.

Поняття «самостійність» невід'ємне від поняття «діяльність». Діяльність є основою всього навчально-виховного процесу. Діяльність, яка приносить успіх і задоволення студенту, стає для нього неабияким чинником розвитку. Саме викладач має постійно стимулювати у студента прагнення піднятися вище того, що ним вже досягнуто. I в той же час сприятливе спілкування студента 3 викладачем і студентів один з одним створює багатогранну гаму стосунків, перетворює процес навчання в духовну потребу. Активізацію пізнавальної діяльності здійснюємо через таку організацію сприйняття навчального матеріалу студентами, при якій засвоєння знань відбувається шляхом розкриття взаємозв'язків між явищами, порівняння нової інформації з відомою, конкретизації, узагальнення, оцінки навчального матеріалу з різних точок зору. Розуміння студентами навчального матеріалу, що вивчається, є лише першою сходинкою в активізації пізнавальної діяльності і тією базою, на основі якої застосовуються інші методи, що вимагають більшої самостійності студентів і розраховані на більш грунтовний розвиток їх логічного мислення.

Підвищення ефективності навчання здійснюємо, використовуючи наступні методи:

- метод евристичної бесіди;

- дискусійний;

- метод рольових ігор;

- метод проектів;

- використання мультимедійних (комп'ютерних)технологій.

В цьому контексті, також широко використовуємо методи та форми навчання, які розвивають комунікативні здібності студентів. Зокрема, це організація роботи в парах, груповий метод навчання, метод проектів, проведення нестандартних занять.

Однією із цікавих форм роботи в цьому напрямку є роздуми над проектом і створення відео 3 повним коментуванням результатів (звичайно цьому передує індивідуальна робота із студентом). Студенти мають нагоду стати співавторами заняття, допомогти своїм одногрупникам краще опанувати тему, демонструючи власне відео. Це сприяє формуванню природничої компетентності майбутніх учителів початкових класів.

\section{Висновки та перспективи подальшого дослідження.}

Підсумовуючи вище сказане, можемо зробити висновок, що самостійна пізнавальна діяльність формується у студентів через їх самореалізацію, самопізнання, бажання досягти нових висот за допомогою різних принципів та методів. А допомогти у цьому може:

- Підвищення професійної майстерності викладача і студента.

- Зацікавлення студентів новими інформаційними технологіями.

- Посилення інтересу до навчання.

- Залучення студентів до пошуку, дослідження.

- Відчутність реальних результатів своєї праці.

- Задоволення в інтелектуальному розвитку.

- Творча самореалізація.

- Задоволення потреби в саморозвитку та самовдосконаленні.

- Заміна авторитарного стилю спілкування демократичним.

- Поглиблення змісту навчального матеріалу.

- Розвиток навичок мислення високого рівня.

- Розвиток креативних здібностей.

- Творче застосування знань.

- Уміння працювати в команді і самостійно.

- Підготовка до конкурсів, науково-дослідницької діяльності.

- Формування навчально-пізнавальної компетентності.

Отже, головну мету навчання вбачаємо не в тому, щоб передати студентам знання в готовому вигляді, а в тому, щоб залучати їх до процесу «здобування» знань, що в свою чергу дозволяє вчити студентів самостійно мислити, ставити перед собою цілі, висувати гіпотези, вибирати відповідні методи для їх досягнення. 
Список бібліографічного опису.

1. Головко Л.Л. Формування досвіду самостійної діяльності студентів вищої сільськогосподарської школи: автореф. дис. на здобуття наук. ступеня канд. пед. наук: спец. 13.00.04 “Теорія та методика професійної освіти” / Л.Л. Головко. - К., 2000. - 16 с.

2. Жалдак М. Комп’ютерно-орієнтовані засоби навчання математики, фізики, інформатики / М. Жалдак, В. Лапінський, М. Шут // Інформатика. - 2006. - № 3-4. - 95 с.

3. Качурівський В.О. Організація самостійної роботи студентів агроколеджів із набуття умінь та навичок практичного застосування комп'ютерної техніки: автореф. дис. на здобуття наук. ступеня канд. пед. наук: спец. 13.00.04 “Теорія та методика професійної освіти" / В.О. Качурівський. - Хмельницький, 2004. - 18 с.

4. Лобода Т.М. Педагогічні умови організації самостійної роботи студентів педагогічного коледжу у процесі викладання української мови: автореф. дис. на здобуття наук. ступеня канд. пед. наук: спец. 13.00.02 “Теорія та методика навчання" / Т.М. Лобода. - К., 2001. - 21 с.

5. Мороз В.Д. Самостійна навчальна робота студентів / В.Д. Мороз. - Х.: ХМК, 2003. - 64 с.

6. Муковіз О.П. Самостійна робота як організаційна форма студентів вищих навчальних закладів / О. Муковіз // Вища освіта України (додаток 1). Тематичний випуск “Педагогіка вищої школи: методологія, теорія, технології” - К.: "Гнозис", 2009. - № 3. - С. 217 - 219.

7. Рубинштейн С.Л. Основы общей психологии / С.Л. Рубинштейн - Спб.: Питер, 2005. - 713 с.

\section{References.}

1. Golovko L.L. Formation of experience of independent activity of students of the higher agricultural school: author's ref. dis. for science. degree of Cand. ped. Science: special. 13.00.04 "Theory and methods of professional education" .- K., 2000. - 16 p.

2. Zhaldak M. Computer-oriented teaching aids for mathematics, physics, computer science / M. Zhaldak, V. Lapinsky, M. Shut. Informatics. - 2006. - № 3 - 4. - 95 p.

3. Kachurivsky V.O. Organization of independent work of students of agricultural colleges on acquisition of abilities and skills of practical application of computer equipment: author's ref. dis. for science. degree of Cand. ped. Science: special. 13.00.04 "Theory and methods of professional education" / V.O. Kachurivsky. - Khmelnytsky, 2004. - 18 p.

4. Loboda T.M. Pedagogical conditions of the organization of independent work of students of pedagogical college in the course of teaching of the Ukrainian language: author's ref. dis. for science. degree of Cand. ped. Science: special. 13.00.02 "Theory and methods of teaching" / T.M. Loboda. - K., 2001. - 21 p.

5. Moroz V.D. Independent educational work of students / V.D. Moroz. - H .: HMK, 2003. - 64 p.

6. Mukoviz O.P. Independent work as an organizational form of students of higher educational institutions / O. Mukoviz / Higher education of Ukraine (Appendix 1). Thematic issue "Higher school pedagogy: methodology, theory, technology" - K .: "Gnosis", 2009. - № 3. - P. 217 - 219.

7. Rubinstein S.L. Fundamentals of general psychology / S.L. Rubinstein - St. Petersburg: Peter, 2005. - 713 p. 